\section{Finland turns to wood and peat for energy}

ONE of the last acts of Finland's outgoing government was to accept, on 15 March, the report of a special commission on energy resources, which advocates $40 \%$ self-sufficiency by 1990 . This programme, which will entail increased use of peat and wood, is effectively a reversal of a previous policy which envisaged a decrease of self-sufficiency from $29 \%$ in 1977 to $23 \%$ in 1990 .

Since Finland's wood processing industry consumes approximately one quarter of all its energy and one third of its electricity, it would seem ecologically appropriate that it provide some of its energy needs. This it already does by providing some electricity generating plants (which in 1977 produced 7.5 TWh of electricity) with fuel in the form of wood wastes. Finland's Centrist Party, however, would like to go further than the commission's proposals and is suggesting an ultimate energy self-sufficiency of $50 \%$. It says that proper use of wood wastes could replace up to $30 \%$ of Finland's oil imports. It is also advocating the growing of "energy woods"--willow and other non-commercial timber. Finland's Forestry Research Institute is at present researching into this possibility, which would have the advantage of using otherwise unprofitable marginal and scrub lands. The main problem however is finance since planting and management of such "energy woods" is highly labour intensive.

According to the 1977 forecasts, Finland's annual consumption of primary energy sources was expected to rise from 23.0 to 33.2 Mtoe by 1990-an increase of some $44 \%$. Of these totals. oil consumption was expected to rise from 12.2 Mtoe in 1977 to 15.9 Mtoe by 1990 . In 1977 , approximately $70 \%$ of Finland's oil imports came from the Soviet Union, and it was hoped that the increase would also come from there.

Recently, however, the Soviet Union has been unable to meet Finland's increased demands, apparently due to similar increases from domestic and Comecon consumers, and difficulties in bringing the new Siberian fields onstream. At the same time, OPEC prices have continued to rise, and the Soviet Union raised its prices proportionally$14 \%$ last December, and a further $8-9 \%$ last week.

Furthermore, Finland's two supertankers are not allowed to pass through the narrows between Denmark and Sweden if loaded to their full 100,000 tonne capacity. A major rethinking of energy policy seemed timely.

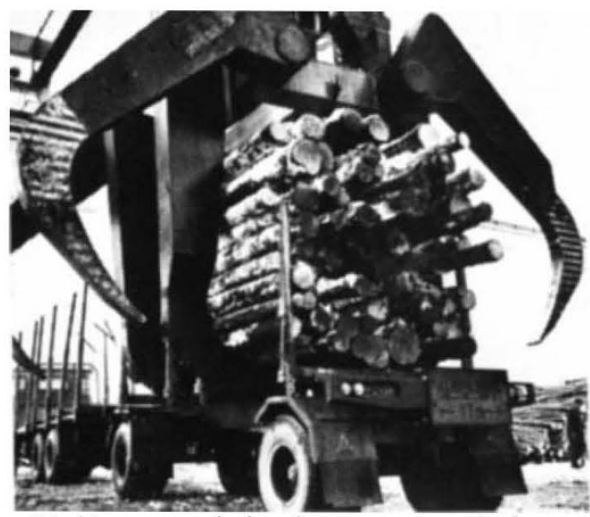

Making a grab for home-grown timber

Being a relatively flat country, Finland has only a limited number of sites suitable for hydroelectric plants, and these are already exploited virtually to full capacity (12.1 TWh in 1977). Nuclear power at present provides some $7 \%$ of all generating capacity from the first set at the Loviisa power station. A second set is under construction at Loviisa and two sets at Okiluto. The possibility of a third nuclear power station with a total capacity of $1 \mathrm{GW}$ is still under discussion, but no decision is expected until the early 1980s.

Finland, incidentally, does not seem to have a vocal anti-nuclear lobby However, on accepting the Soviet tender for the Loviisa plant, the Finns demanded far more stringent safety precautions than were then normal for Soviet reactors, including containment buildings (seen by the Soviet designers as a capitalist trick for inflating construction costs), redundant cooling systems and improved computerised controls. When the Soviet Union was unable to supply these additions, the Finns went shopping in Holland, West Germany and the USA.

Nuclear power, however, depends on foreign suppliers, not only for the construction of the station (the Soviet Union for Loviisa and Sweden for Okiluto) but also for nuclear fuel. If Finland is to become relatively more selfsufficient, wood and peat will become considerably more important.

Until very recently, peat which at present accounts for only $1 \%$ of Finland's energy production, had not been considered a commercially viable alternative. Earlier this month, however, the then Minister of Trade and Industry, E. Rantala announced a new agreement between Neste Oy, the Imatra Power company and the Navire Company on the study and adoption of wet carbonisation. This process removes most of the water from the peat, giving a fuel that is comparable with coal and contains only some $10 \%$ of water. Liquefaction of peat, said Mr Rantala, is also to be studied and the next supplementary budget is expected to allot additional funds for peat research.

Vera Rich

\section{Hungary's careful use of pesticides for plant protection}

"Chemical pesticides, even if used extensively, never harm the wild life economy, provided that they are applied professionally.', So said Mr Ferens Hargetai, head of the plant protection department of the Hungarian Ministry of Agriculture, at a seminar in Cambridge, England last week.

Hargetai's statement might well alarm some ecologists, particularly when joined to his definition of environmental protection. By this, he said, "we mean, whether confessed or not, the human being rather than the environment itself. Speaking about environment protection, one never thinks of the protection of the Colorado beetle or house fly, though these also belong to the environment in the same way as the singing birds or the national parks do",

However Dr Illes Desi, of the National Institute of Hygiene, suggested at the seminar, that developing an appropriate pesticide strategy was by no means simple. "More pesticides", he told Nature, "mean more food-but also more pollution."

The Cambridge seminar was part of the UK-Hungary trade and technology cooperation programme, and it was the Hungarians who asked specifically for a meeting on pesticides. Hungary has an excellent record of awareness of pesticide hazard. Mr Hargetai said it was the first country in the world to ban DDT, aldrin, dieldrin and $\mathrm{HCH}$. "We found that the concentration of DDT in the population was very high-12 to 16 ppm. This was among the highest in the world. So it had to be stopped"

In the same year (1968), a set of requirements for the registration of pesticides was drawn up. In 1972, a new system was introduced classifying pesticides from the point of view of environmental hazard. This meant certain pesticides could not be used within a given distance of a river; some may only be applied by trained experts.

These experts play an important role in Hungarian agricultural planning. By law, every state farm must have on its staff a "plant protection engineer". Cooperatives and the few remaining private farms can (and in the case of dangerous pesticides, must) hire the relevant experts from the government-sponsored Plant Protection Service.

This service is concerned with the whole range of plant management problems including research into crop pests and diseases. In 1975 a forecasting system began which has reduced considerably the amount of pesticide needed. 